\title{
TINJAUAN KRITIS: RESTORASI MINOR DAN MAYOR PADA HUNIAN TRADISIONAL CAGAR BUDAYA DI INDONESIA STUDI KASUS RUMAH TUO KAMPAI NAN PANJANG DAN RUMAH WAE REBO
}

\author{
Ari Widyati Purwantiasning \\ Jurusan Arsitektur Universitas Muhammadiyah Jakarta \\ arwityas@yahoo.com
}

\begin{abstract}
ABSTRAK. Tulisan ini merupakan sebuah tinjauan kritis tentang penerapan restorasi minor dan mayor pada hunian tradisional terutama yang ditetapkan menjadi cagar budaya di Indonesia. Studi kasus yang terpilih untuk diulas dalam tulisan ini adalah Rumah Tuo Kampai Nan Panjang yang terdapat di Sumatera Barat dan Rumah Wae Rebo yang terdapat di Flores. Tujuan dari penulisan ini adalah untuk dapat memahami lebih dalam tentang praktek kegiatan restorasi baik minor dan mayor terutama pada bangunan cagar budaya, dimana dalam hal ini difokuskan pada bangunan hunian tradisional. Metode yang digunakan dalam tinjauan kritis ini adalah kualitatif naratif deskriptif, dimana penulis memaparkan secara deskriptif kedua studi kasus dengan mengacu pada panduan UndangUndang Cagar Budaya Indonesia No. 10 Tahun 2011 dan panduan prinsip-prinsip konservasi cagar budaya di Cina yang dianggap memiliki similaritas dalam penerapannya.
\end{abstract}

Kata Kunci: restorasi minor, restorasi mayor, cagar budaya, Rumah Tuo Kampai Nan Panjang, Rumah Wae Rebo

\begin{abstract}
This paper is a critical review of how the application of major and minor restoration for traditional houses, particularly, which have been designated as a cultural heritage in Indonesia. We have conducted two case studies; they are Rumah Tua Kampai Nan Panjang located in West Sumatera and Rumah Wae Rebo in Flores. This paper aims to understand deeply about the application of restoration, either minor or major, particularly for a cultural heritage building; in this case, we will focus on traditional houses. A qualitative method has been conducted in this critical review by using the narrative descriptive approach. The research also refers to Undang-Undang Cagar Budaya Indonesia No. 10 Tahun 2011 and the guidelines of the principles of conservation for cultural heritage in China.
\end{abstract}

Keywords: minor restoration, major restoration, cultural heritage, Rumah Tuo Kampai Nan Panjang, Rumah Wae Rebo

\section{PENDAHULUAN}

Bahri \& Purwantiasning (2016) menjelaskan dalam satu penelitiannya, bahwa pemanasan global telah membuka mata dan kepedulian semua pihak dalam kegiatan preservasi terutama yang berkaitan dengan alam dan lingkungan binaan. Salah satu kegiatan preservasi tersebut adalah kegiatan pelestarian terhadap bangunan-bangunan tradisional khususnya yang ada di Indonesia. Banyaknya bangunan tradisional di Indonesia mendorong inisiatif berbagai pihak dalam menangani masalah pelestarian bangunanbangunan tradisional tersebut,

Tulisan ini akan membahas tentang bagaimana penerapan salah satu prinsip konservasi yang ada di dalam dokumen prinsip-prinsip konservasi pada situs heritage di Cina. Beberapa contoh akan diberikan sebagai gambaran tentang prinsip ini yaitu prinsip "On Minor and Major Restoration", prinsip Restorasi Minor dan Mayor pada satu kasus situs maupun bangunan bersejarah. Sebelum memulai ulasan, akan dibahas juga tentang terminologi apa itu minor, mayor dan juga restorasi.

Merujuk pada dokumen The Principles of the Conservation of Heritage Sites in China (The Getty Conservation Institute, 2002), maka dapat dijelaskan bahwa tujuan dari restorasi minor dan mayor ini adalah untuk memulihkan dari bahaya yang mengancam struktur bangunan, untuk memperbaiki komponenkomponen bangunan yang rusak dan untuk mengembalikan kondisi situs bersejarah ataupun bangunan bersejarah pada kondisi awalnya.

Kedua tipe intervensi tersebut baik minor maupun mayor ini harus mengikuti prinsipprinsip berikut ini:

1. Komponen asli harus dipertahankan
semaksimal mungkin. Komponen-
komponen yang rusak yang diperbaiki 
harus digunakan kembali daripada menggunakan atau digantikan oleh komponen lainnya. Komponen-komponen yang dianggap cukup tua atau dapat mengakibatkan teknik konstruksi yang aneh atau tidak biasa (unik), tidak boleh digantikan. Komponen-komponen tersebut harus dapat dipertahankan dengan memperbaikinya.

2. Sangat memungkinkan untuk menambahkan sedikit jumlah komponenkomponen baru untuk mendukung keberadaan struktur asli bila memang dianggap tidak aman atau bila intervensi sebelumnya sudah dilakukan.

3. Dalam melakukan perbaikan, tidak diperbolehkan untuk melakukan pengecatan ulang bagi lukisan dekoratif baik untuk efek baru maupun lebih dominan. Lukisan dekoratif yang dianggap unik dan bernilai tinggi karena usia maupun disainnya, hanya dapat diperlakukan dengan perhitunganperhitungan yang dianggap protektif.

4. Setiap teknik dan material yang dianggap menguntungkan bagi konservasi situs dapat dipertimbangkan untuk digunakan, namun material dan teknik tradisional dari nilai-nilai yang spesifik harus dipertahankan

Bila perlindungan terhadap isi dari bangunan maupun situs bersejarah tidak dapat dipastikan selama kegiatan restorasi, maka isi tersebut harus dipindahkan untuk sementara kemudian dapat diletakkan kembali setelah kegiatan restorasi berakhir. Situs bersejarah yang rusak karena bencana alam maupun kerusakan yang dilakukan oleh manusia, dapat direstorasi jika terdapat bukti-bukti cukup bahwa memang bangunan maupun situs tersebut layak disebut sebagai cagar budaya atau heritage. Dalam hal ini, kegiatan restorasi minor dan mayor dapat dikategorikan sebagai perbaikan dari sebuah bangunan maupun situs bersejarah.

Sementara itu bila merujuk pada UndangUndang RI No. 11 Tahun 2010 tentang Cagar Budaya (2010), disebutkan bahwa ada beberapa pengelolaan dan pemeliharaan Cagar Budaya yaitu diantaranya perlindungan, pemeliharaan dan pemugaran. Di dalamnya dipaparkan mengenai arti dari masing-masing pengelolaan tersebut, perlindungan didefinisikan sebagai upaya mencegah dan menanggulangi dari kerusakan, kehancuran atau kemusnahan dengan cara Penyelamatan, Pengamanan, Zonasi, Pemeliharaan dan Pemugaran Cagar Budaya. Pemeliharaan didefinisikan sebagai upaya menjaga dan merawat agar kondisi fisik Cagar Budaya tetap lestari. Dan Pemugaran adalah upaya pengembalian kondisi fisik Benda Cagar Budaya, Bangunan Cagar Budaya, dan Struktur Cagar Budaya yang rusak sesuai dengan keaslian bahan, bentuk, tata letak, dan/ atau teknik pengerjaan untuk memperpanjang usianya.

Jika melihat pada prinsip-prinsip konservasi pada dokumen The Principles of the Conservation of Heritage Sites in China (The Getty Conservation Institute, 2002), maka kata "on minor dan major restoration" dalam hal ini kata "restoration" mengacu pada kata "pemugaran" dalam Undang-Undang RI No. 11 Tahun 2010 tentang Cagar Budaya (2010). Keduanya memiliki benang merah yang sama yaitu mengembalikan kondisi fisik Cagar Budaya sesuai kondisi semula.

Hal ini diperkuat dengan Paragraf 5 tentang Pemugaran Pasal 55 di dalam UndangUndang RI No. 11 Tahun 2010 tentang Cagar Budaya (2010) yang berisi tentang beberapa hal yaitu:

(1) Pemugaran Bangunan Cagar Budaya dan Struktur Cagar Budaya yang rusak dilakukan untuk mengembalikan kondisi fisik dengan cara memperbaiki, memperkuat, dan/atau mengawetkannya melalui pekerjaan rekonstruksi, konsolidasi, rehabilitasi, dan restorasi.

(2) Pemugaran Cagar Budaya sebagaimana dimaksud pada ayat (1) harus memperhatikan:

a. keaslian bahan, bentuk, tata letak, gaya, dan/atau teknologi pengerjaan;

b. kondisi semula dengan tingkat perubahan sekecil mungkin;

c. penggunaan teknik, metode, dan bahan yang tidak bersifat merusak; dan

d. kompetensi pelaksana di bidang pemugaran.

(3) Pemugaran harus memungkinkan dilakukannya penyesuaian pada masa mendatang dengan tetap mempertimbangkan keamanan masyarakat dan keselamatan Cagar Budaya.

(4) Pemugaran yang berpotensi menimbulkan dampak negatif terhadap lingkungan sosial dan lingkungan fisik harus didahului analisis mengenai dampak lingkungan sesuai dengan ketentuan peraturan perundang-undangan.

(5) Pemugaran Bangunan Cagar Budaya dan 
Struktur Cagar Budaya wajib memperoleh izin Pemerintah atau Pemerintah Daerah sesuai dengan kewenangannya.

(6) Ketentuan lebih lanjut mengenai Pemugaran Cagar Budaya diatur dalam Peraturan Pemerintah.

\section{TERMINOLOGI RESTORASI}

Restoration berasal dari kata "restore", yang berarti mengembalikan ke kondisi awalnya. Kata restore itu sendiri berasal dari Bahasa Latin yaitu "restaurate" yang berarti "membangun kembali" atau "mengembalikan", yang kemudian juga berkembang dari Bahasa Perancis Kuno yaitu "restorer" yang memiliki arti yang sama yaitu "mengembalikan". Bila ditilik dari asal usul kata tersebut maka kata restore dapat diartikan sebagai "mengembalikan", "memulihkan", "memperbaiki", "memugar", "memulangkan", dimana kesemuanya memiliki makna yang sama yaitu mengembalikan ke kondisi awalnya.

Dari paparan di atas, dapat dipahami bahwa restorasi merupakan suatu kegiatan atau proses yang berkaitan dengan proses mengembalikan sesuatu yang rusak atau hancur ke dalam kondisi awalnya. Sehingga restorasi jika dikaitkan dengan benda bersejarah dapat dikatakan sebagai proses yang bertujuan untuk mengembalikan kondisi benda bersejarah tersebut ke dalam beberapa kondisi sebelumnya yang dapat tetap memperlihatkan keasliannya. Kegiatan atau proses restorasi ini sudah dikenal sejak jaman setelah revolusi industri, dimana banyak sekali peninggalan-peninggalan sejarah, terutama benda-benda bersejarah seperti lukisan dan arca-arca yang hancur, dan penting untuk dipulihkan kondisinya.

Restorasi merupakan salah satu kegiatan atau proses dari pelestarian bangunan maupun situs bersejarah. Kutipan dari UNESCO (2005), memaparkan bahwa restorasi dapat dipahami dalam dua konteks, restorasi dalam kontek luas dapat diartikan sebagai "kegiatan mengembalikan bentukan fisik suatu tempat atau benda pada kondisi sebelumnya dengan menghilangkan tambahan-tambahan atau merakit kembali komponen eksisting menggunakan material baru". Sementara itu restorasi dalam konteks terbatas adalah "kegiatan pemugaran untuk mengembalikan bangunan dan lingkungan cagar budaya semirip mungkin ke bentuk asalnya berdasarkan data pendukung tentang bentuk arsitektur dan struktur keadaan asal tersebut dan agar persyaratan teknik terpenuhi."

Saat ini proses dan kegiatan restorasi dianggap penting, karena banyaknya keberadaan benda-benda bersejarah khususnya bangunan dan situs bersejarah yang makin hari makin hancur karena dimakan usia maupun karena minimnya pemeliharaan. Oleh karenanya sebagai salah satu usaha untuk mempertahankan keberadaannya demi kepentingan generasi masa depan, maka kegiatan dan proses restorasi ini perlu dilakukan. Beberapa hal yang perlu ditekankan di sini, bahwa kegiatan dan proses restorasi ini dianggap sebagai sesuatu yang kontroversial, karena satu pihak yang mendukung adalah demi kelangsungan sejarah, sementara pihak lain berpendapat bahwa material dari benda bersejarah tersebut akan berubah sehingga dapat merusak nilai dari benda bersejarah tersebut. Pada akhirnya dapat ditetapkan bahwa pada kegiatan restorasi ini terdapat dua kategori yaitu restorasi minor dan restorasi mayor.

\section{Restorasi Minor}

Merujuk pada dokumen dalam The Principles of the Conservation of Heritage Sites in China (The Getty Conservation Institute, 2002), restorasi minor dari bangunan maupun situs bersejarah meliputi dua kategori intervensi. Yang pertama adalah bagaimana mengembalikan stuktur dan komponen yang membahayakan ke dalam kondisi yang stabil dan aman sesuai dengan kondisi bangunan dan situs bersejarah tersebut, dan yang kedua adalah pemindahan struktur dan komponen tambahan yang dianggap tidak memiliki nilai bagi bangunan dan situs bersejarah tersebut. Perlakuan dari kedua kondisi tersebut harus disesuaikan dan memenuhi prinsip-prinsip berikut ini:

1. Komponen-komponen yang rusak, salah tempat dan juga hancur harus dikembalikan pada kondisi awal saat tidak terjadi intervensi atau gangguan terhadap struktur bangunan, tambahan-tambahan komponen selanjutnya yang dianggap tidak memiliki nilai, harus dihilangkan.

2. Saat proses restorasi berlangsung pada situs atau bangunan bersejarah untuk menyelamatkan dan menstabilkan kondisi bersejarahnya tersebut, sangat dimungkinkan untuk memperbaiki atau menambahkan material baru seminimal mungkin, namun tidak diperbolehkan untuk menggantikan material lama dengan material baru dalam jumlah yang 
dianggap terlalu besar/ banyak.

3. Rujukan-rujuan harus diberikan dalam menggunakan teknik-teknik tradisional

4. Hal-hal yang dianggap sebagai pengingat periode sejarah tertentu yang berbedabeda dan dianggap penting harus dipertahankan semaksimal mungkin. Tidak perlu untuk menghilangkannya hanya karena gaya arsitektur tertentu atau untuk mengejar penampilang bangunan yang tentunya akan merusak nilai sejarahnya.

\section{Restorasi Mayor}

Dalam dokumen The Principles of the Conservation of Heritage Sites in China (The Getty Conservation Institute, 2002), yang dimaksud dengan major restoration atau restorasi mayor/ besar adalah adanya intervensi yang melibatkan sebagian besar pada material aslinya. Biasanya hal ini termasuk dalam pengembalian struktur menjadi kondisi yang stabil dan juga memperbaiki atau menggantikan bagianbagian atau komponen-komponen yang rusak atau hilang. Keputusan dalam memperbaiki arsitektur kayu tradisional melalui perombakan menambahkan atau mengurangi komponen harus dilakukan melalui studi kelayakan sebab dan akibat. Semua masalah yang muncul akibat proses atau kegiatan penambahan atau pengurangan komponan ini harus dilakukan dengan sebenar-benarnya dan setepattepatnya. Kegiatan dan proses restorasi semaksimal mungkin harus dapat mempertahankan struktur, komponen dan melacak periode waktu sejarah yang berkaitan dengan nilai-nilai sejarah dari bangunan tersebut.

Restorasi mayor biasanya melibatkan intervensi yang besar pada kondisi fisik. Tahapan survei, perencanaan dan perancangan harus dilakukan dengan perhatian sepenuhnya pada detail-detail komponen, sehingga informasi dan data-data yang berkaitan dengan kondisi eksisting dari situs atau bangunan bersejarah harus dipertimbangkan matang-matang, serta prosedur dari evaluasi juga harus dilakukan oleh tenaga ahli untuk disetujui dengan mempertimbangkan berbagai aspek.

Kegiatan dan proses restorasi harus mempertimbangkan prinsip-prinsip di bawah ini:

1. Restorasi mayor melalui pelepasan/ pembongkaran struktur harus dihindari semaksimal mungkin, namun jenis lain dari intervensi dapat diterapkan sebagai usaha untuk mempertahankan struktur asli agar aman dan stabil. Pembongkaran sebagian atau menyeluruh dapat diperbolehkan jika struktur utama dianggap hancur atau rusak secara serius dan komponen-komponen utamanya sangat rusak sehingga dapat mengganggu keamanan dan kestabilan dari bangunan, sehingga tidak memungkinkan jika tanpa adanya pembongkarang. Restorasi melalui pembongkaran seharusnya menghilangkan seluruh elemen yang dianggap tidak aman dan dipastikan tidak akan ada perawatan lebih lanjut untuk periode yang cukup lama.

2. Selama proses restorasi mayor, diperbolehkan untuk memberikan struktur baru, menggunakan substansi baru yang menguatkan, dan mengganti komponenkomponen yang rusak. Penambahan baru pada struktur asli harus ditempatkan pada bagian yang tersembunyi dari pandangan langsung, dan komponen-komponen pengganti harus ditandai dengan penanggalan.

3. Pada prinsipnya, pelacakan dari keberadaan komponen-komponen maupun bahan/ material bangunan dari berbagai periode waktu yang berbedabeda harus terdokumentasi dengan baik. $\mathrm{Hal}$ ini untuk mengingatkan seberapa tinggi nilai sejarah dari bangunan tersebut sebagai cagar budaya, dan juga sebagai penanda apakah komponen-komponen tersebut layak untuk dilestarikan. Elemenelemen maupun bagian-bagian yang digantikan atau dihilangkan, harus disimpan dan didokumentasikan dalam arsip situs.

4. Restorasi mayor memungkinkan untuk menggantikan bagian-bagian yang hilang dari situs cagar budaya, dimana bagianbagian penggantinya tersebut dianggap tepat dan layak untuk menggantikannya yang dikaitkan dengan kondisi bersejarahnya situs tersebut. Penambahan material/ bahan bangunan harus diberi label dengan tanggal saat penggantiannya. Pahatan, lukisan, artefak, lukisan dan berbagai hal dekoratif lainnya yang rusak pada permukaan arsitektur kayu maupun karya cagar budaya lainnya, harus dilindungi sesuai kondisi awalnya untuk menghindari kerusakan lebih lanjut.

5. Bila seluruh layout bangunan masih relatif utuh atau tidak rusak, maka kegiatan atau proses restorasi dapat dipertimbangkan dengan merekonstruksi sejumlah kecil dari bagian-bagian bangunan yang hilang, 
yang berarti harus melestarikan seluruh keintegritasas dari kompleks tersebut.

\section{METODE}

Tulisan ini merupakan sebuah tinjauan kritis terhadap aplikasi kegiatan restorasi baik minor maupun mayor pada bangunan hunian yang menjadi cagar budaya. Tulisan dihasilkan dengan menggunakan metode kualtatif deskriptif naratif, dengan mengacu pada peraturan perundangan yang ada di Indonesia dan dibandingkan dengan prinsip-prinsip konservasi dari buku panduan situs cagar budaya Cina. Prinsip-prinsip konservasi dari buku panduan cagar budaya Cina ini dianggap paling mirip dengan kondisi yang ada di Indonesia, baik kondisi bangunannya itu sendiri maupun kondisi non fisik yang ada di lingkungan sekitar bangunan cagar budaya tersebut.

\section{HASIL PENELITIAN DAN PEMBAHASAN}

Mengacu pada pembahasan sebelumnya yang telah memaparkan apa dan bagaimana penerapan restorasi minor dan mayor. Maka pada bagian ini akan dipaparkan kedua intervensi tersebut dengan memberikan dua studi kasus yang berbeda dalam kegiatan restorasinya.

Contoh kegiatan dan proses restorasi minor ini dapat dilihat pada studi kasus di bawah ini, yaitu pada Rumah Tuo Kampai Nan Panjang di Sumatera Barat:

Pada gambar 1 dan 2 diperlihatkan bangunan tua di Sumatera Barat yaitu Rumah Tuo Kampai Nan Panjang, yang masuk dalam Situs Cagar Budaya. Rumah ini dianggap memiliki sejarah yang tinggi karena rumah gadang ini didirikan oleh seorang Datuk dari Suku Kampai Nan Panjang lebih kurang 300 tahun yang lalu. Bangunan ini terletak di Nagari Belimbing, sekitar 13 km dari Batusangkar, Sumatera Barat. Sebagian besar bangunan ini belum mengalami perubahan baik dari segi struktur bangunan maupun bahan bangunan. Dari gambar di atas terlihat struktur bangunan masih terlihat asli, sehingga tiang-tiang struktur yang miring juga masih terlihat asli seperti apa adanya. Pada gambar 2 diperlihatkan lubang berbentuk oval yang fungsinya adalah sebagai pintu penghubung ke ruangan lainnya, yaitu ruang-ruang yang lebih privat (kamar tidur), bentuk aslinya masih dipertahankan sedemikian rupa, sehingga tidak menghilangkan nilai-nilai dari rumah tersebut.
Rumah Tua Kampai Nan Panjang yang telah ditetapkan sebagai Situs Cagar Budaya sesuai dengan UU RI No. 5 Tahun 1992 (lihat gambar 3), ini merupakan rumah yang memiliki arsitektur bergaya khas Minang yaitu rumah gadang dengan atap yang bergonjong empat dan terbuat dari ijuk. Keseluruhan bangunan bagian luar terdiri dari kayu berwarna hitam. Bangunan rumah ini hanya memiliki satu pintu masuk ke bagian dalam rumah dan memiliki tangga tepat berada di tengah-tengah bangunan rumah.
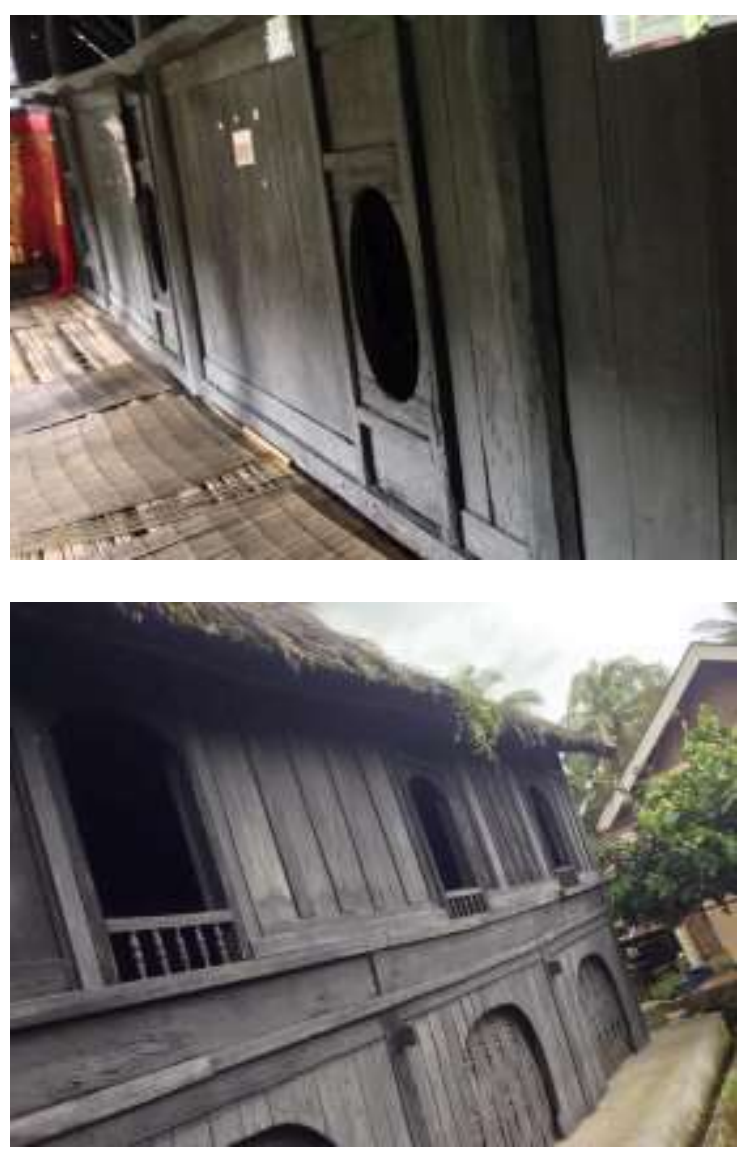

Gambar 1 dan 2: Material asli dari bangunan Rumah Tuo Kampai Nan Panjang masih dipertahankan dan umurnya sudah mencapai lebih dari 300 tahun

(Sumber: dokumentasi pribadi, 2014)

Sampai saat ini bangunan rumah gadang tua ini masih dipertahankan keasliannya, sehingga bentuk, struktur dan material bangunan tersebut dapat menceritakan kepada generasa masa kini dan masa mendatang bagaimana tuanya bangunan tersebut. Kegiatan dan proses restorasi dilakukan sebagai usaha untuk mempertahankan keberadaan bangunan ini, baik dari segi keamanan maupun kekuatan dari bangunan tersebut, walaupun sudah tidak dihuni lagi, namun bangunan ini masih berdiri 
kokoh. Kegiatan restorasi hanya sebatas pada pembersihan dan pengelolaan material berupa kayu hitam supaya tidak lapuk dan dapat bertahan sampai ratusan tahun.

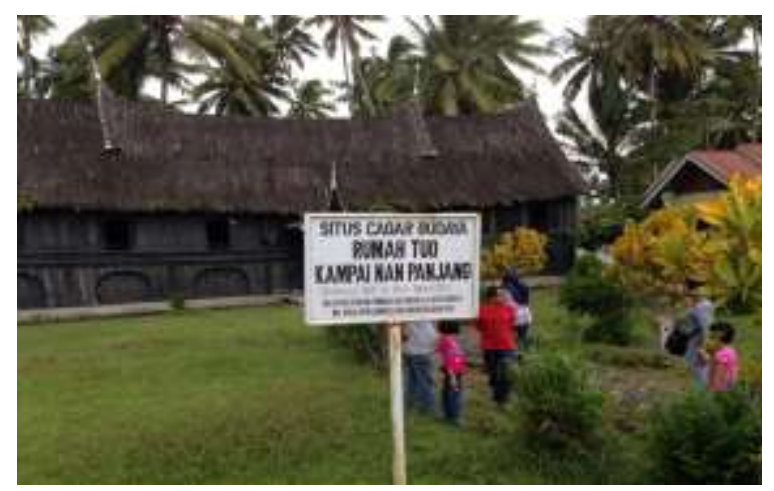

Gambar 3: Rumah Tuo Kampai Nan Panjang yang ditetapkan sebagai Situs Cagar Budaya sesuai UU No. 5 tahun 1992

(Sumber: dokumentasi pribadi, 2014)

Yang menjadi unik dari Rumah Tuo Kampai Nan Panjang ini adalah, seperti layaknya rumah gadang umumnya, rumah ini juga dibangun dengan menggunakan tukangtukang yang mengerti tradisi dan upacara dalam adat membangun sebuah rumah tradisional. Rumah ini juga dibangun tanpa menggunakan paku, hanya dengan menggunakan pasangan pasak kayu dan sambungan kayu tanpa paku.

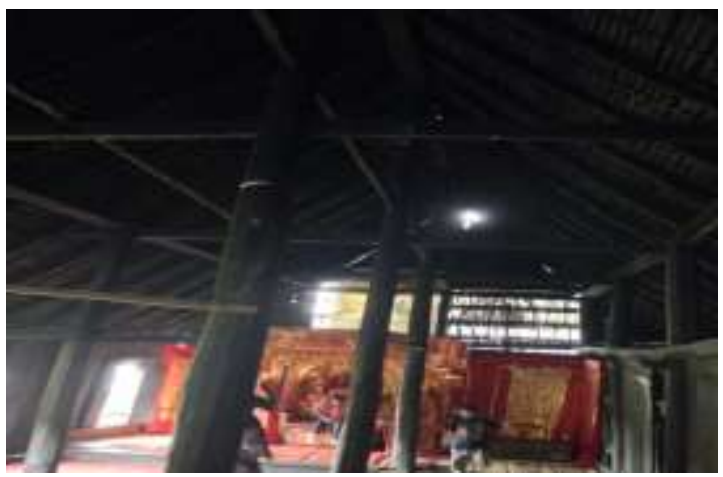

Gambar 4: Struktur rangka atap dan tiang-tiang di dalam Rumah Tuo Kampai Nan Panjang yang terlihat langsung karena tanpa penutup plafond

(Sumber: dokumentasi pribadi, 2014)

Rumah Tuo Kampai Nan Panjang juga tidak memiliki plafon (lihat gambar 4), sehingga kuda-kuda kayu yang saling tersusun dan melintang dapat terlihat jelas sebagai rangka atapnya. Lantai pada rumah yang tergolong sebagai rumah panggung ini juga dilapisi bilah bambu yang bersusun-susun, dan relatif rata lantainya, ada ada bagian yang lebih tinggi yaitu pada bagian menuju kamar dengan satu buah anak tangga dari ujung kiri ke kanan. Hal inilah yang juga dipertahankan keasliannya, sehingga dapat dirasakan kekuatannya dari struktur atap dan bangunan ini oleh generasi saat ini maupun generasi masa mendatang.

Di lain pihak, berikut ini dapat dilihat contoh dari restorasi mayor yang ada di Indonesia. Pada gambar 5 ("Membangun Mbaru NiangRumah Tradisional Waerebo," 2014) diperlihatkan bagaimana situs cagar budaya Waerebo berusaha untuk bertahan dari periode waktu ke periode waktu mendatang. Desa Waerebo yang berada di Barat Daya Kota Ruteng, Kabupaten Manggarai, Nusa Tenggara Timur, merupakan situs cagar budaya yang dahulunya memiliki 7 buah rumah adat warisan leluhur berbentuk kerucut. Rumah adat di Desa Waerebo yang disebut dengan Mbaru Niang ini pada tahun 2012 mendapatkan penghargaan dari UNESCO Asia-Pasifik sebagai salah satu hasil kegiatan Konservasi Warisan Cagar Budaya yaitu Award of Excellent dalam bidang kategori culture and tourism category, yang merupakan penghargaan tertinggi untuk Konservasi Warisan Cagar Budaya, dan menjadi kandidat sebagai peraih penghargaan Aga Khan Award dalam bidang arsitektur pada tahun 2013.

Purwantiasning (2017) memaparkan dalam penelitian sebelumnya bahwa sebuah desa tradisional yang memiliki sejarah tertentu, ditengarai memiliki nilai budaya dan tradisi yang khas dan patut dipertahankan. Hal ini dilakukan tidak hanya semata-mata untuk kepentingan pariwisata, namun juga untuk keberlangsungan dan keberlanjutan dari desa tradisional tersebut. Sejarah sebuah desa tradisional juga dapat bermanfaat bagi generasi masa depan dalam mempelajari nilainilai budaya yang terbentuk di masa lampau, sehingga menjadi lebih berharga.

Mbaru Niang yang berarti Rumah Drum ini memiliki keunikan tersendiri, karena bentuknya yang mengerucut ke atas, dan dibangun secara tradisional. Awal mulanya, Mbaru Niang terdiri dari 7 buah bangunan, namun karena terjadinya bencana kebakaran dan mulai lapuknya struktur bangunan, maka Mbaru Niang yang dapat bertahan hanya tinggal 4 bangunan.

Dengan kegiatan dan proses pelestarian cagar budaya dengan restorasi, maka Mbaru Niang yang sudah hancur tersebut dapat direstorasi menjadi pulih kembali seperti kondisi awalnya. 
Pembangunan Mbaru Niang yang sudah hancur tersebut, melalui upacara adat dan juga menggunakan teknik-teknik tradisional oleh bangunan komunal yang dapat mengakomodasi enam sampai dengan delapan keluarga dalam satu bangunannya, terdiri dari struktur lima tingkat, dimana setiap

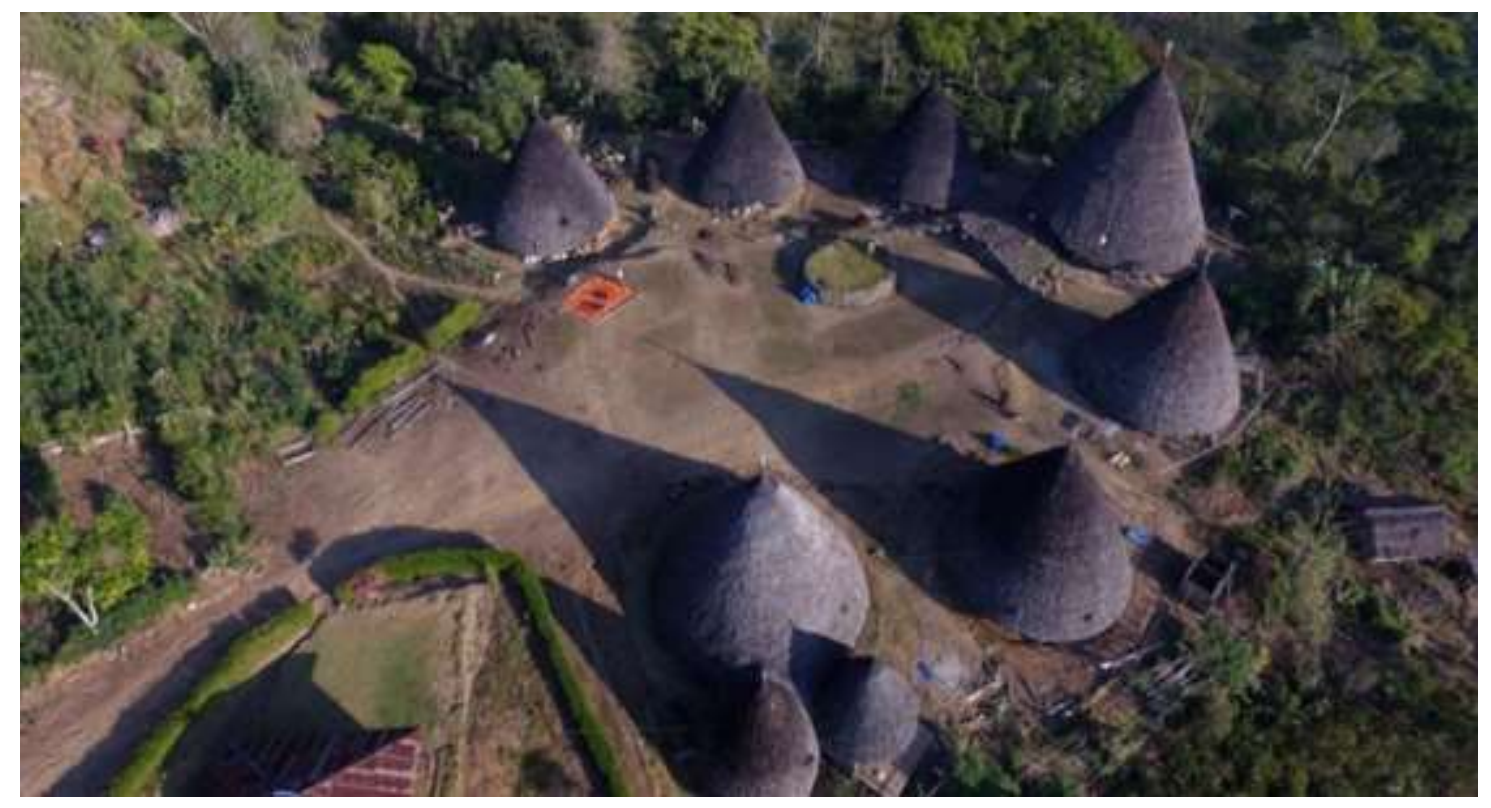

Gambar 5: Desa Waerebo, Flores dengan 7 buah bangunan Mbaru Niang

para sesepuh di Desa Waerebo.

Atap besar yang terbuat dari ijuk hampir menyentuh tanah dan didukung dengan sebuah tiang kayu besar sebagai struktur utama, memang sangat rentan terhadap bahaya kebakaran. Hal ini diperkuat karena adanya perapian yang terletak di tengah rumah tersebut.

Nilai-nilai sejarah dengan leluhur yang dipertahankan oleh masyarakat Dewa Waerebo adalah bentuk bangunan Mbaru Niang yang berbentuk kerucut, melingkar dan berpusat di tengah yang diyakini oleh mereka sebagai lambang persaudaraan yang tidak pernah putus dengan leluhur mereka sebagai titik pusatnya. Mbaru Niang yang merupakan tingkatnya memiliki nama dan fungsi masingmasing.

Kegiatan dan proses restorasi Mbaru Niang di Desa Waerebo, Flores melalui upacara adat dari mulai perletakan pondasi pertama, naiknya tiang pusat, sampai dengan pemasangan struktur atap dan penutup atap ijuk, semuanya melalui proses tradisional dengan upacara adat. Pekerjaan dilakukan dengan teknik tradisional dengan menggunakan material yang didapatkan di sekitar Desa Waerebo. Hal ini mengingat sangat kentalnya nilai-nilai yang ditanamkan oleh leluhur masyarakat Desa Waerebo, sehingga dalam setiap kegiatan semuanya harus didasari oleh nilai tradisi dan adat (Antar, 2010). 
Restorasi di Rumah Wae Rebo ini dianggap sebagai restorasi mayor karena seluruhnya menggunakan material baru dan membangun kembali apa yang sudah hancur sebelumnya dengan mengikuti bentuk-bentuk dan pola ruangan serta disain yang sama dengan sebelumnya.

Dengan adanya kegiatan restorasi di Rumah Wae Rebo ini, diharapkan nilai-nilai tradisional, budaya dan juga adat istiadat masih dapat dilestarikan baik oleh penduduk setempat sebagai pengguna langsung, maupun bagi masyarakat Indonesia sebagai sebuah pembelajaran akan pentingnya nilai Cagar Budaya. Kegiatan yang dilakukan ini dianggap sebagai sebuah tradisi lisan yang dilakukan turun temurun dari generasi tua ke generasi muda, dari satu generasi ke generasi lainnya, sehingga diharapkan ada keberlanjutan di dalam proses pelestarian tradisi ini.

Sebagaimana disampaikan Purwantiasning, et.al (2018) bahwa tradisi lisan merupakan sebuah tradisi yang disampaikan secara turun temurun dari satu generasi ke generasi lainnya sehingga dapat mempertahankan dan melestarikan apa yang sudah ada sebelumnya. Tradisi lisan ini dapat berupa rangkaian upacara adat yang dilakukan pada satu kelompok masyarakat tertentu dan dapat juga berupa suatu tradisi yang ditanamkan dari sejak pertama kali terbentuknya satu kelompok masyarakat tertentu. Merujuk pada hal ini, maka kegiatan yang dilakukan oleh masyarakat Wae Rebo dalam melestarikan bangunan tradisionalnya yaitu Mbaru Niang dengan segala ritual upacara tradisional tersebut dapat dikatakan sebagai sebuah tradisi lisan yang patut untuk dilestarikan. Keberlangsungan dari sebuah bangunan tradisional juga dapat dipertahankan dengan adanya transfer pengetahuan dari para sesepuh kepada generasi muda dalam hal ilmu merakit atau membangun sebuah rumah, yang disebut sebagai tradisi lisan.
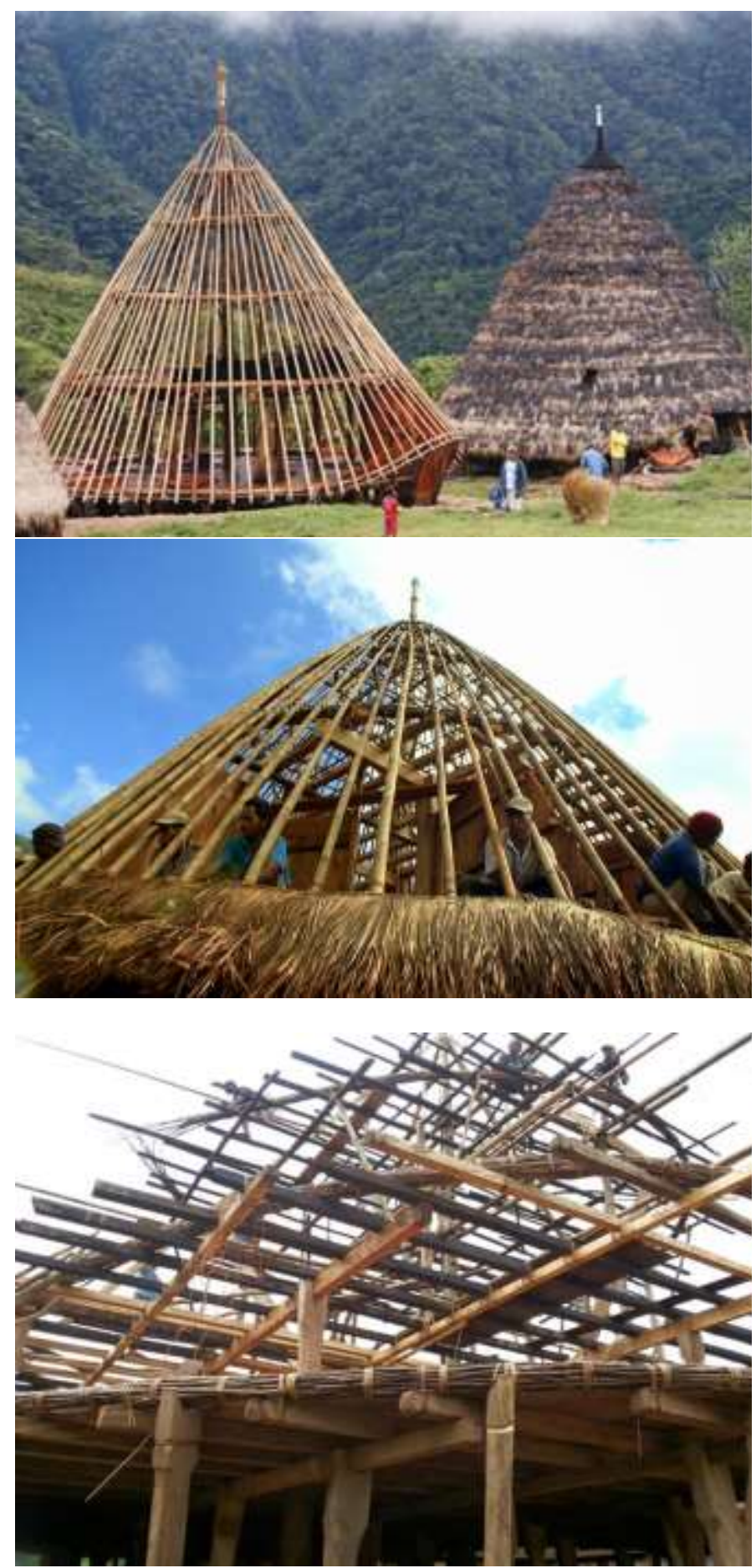

Gambar 6,7,8: Proses restorasi Mbaru Niang di Desa Waerebo, Flores

(Sumber: https://bandanaku.wordpress.com, diakses 08 Mei 2017) 

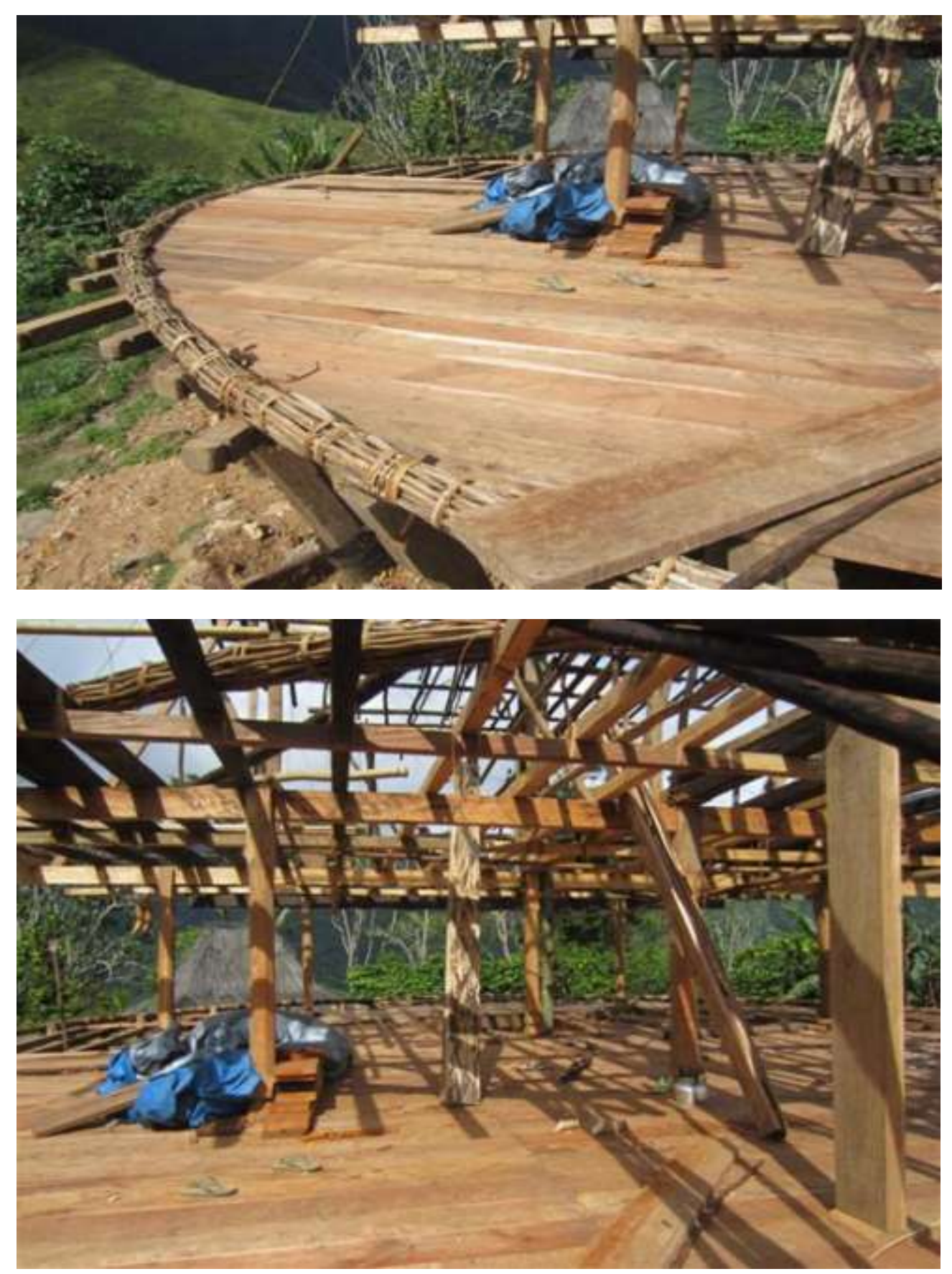

Gambar 9,10: Proses restorasi Mbaru Niang di Desa Waerebo, Flores

(Sumber: https://bandanaku.wordpress.com, diakses 08 Mei 2017) 

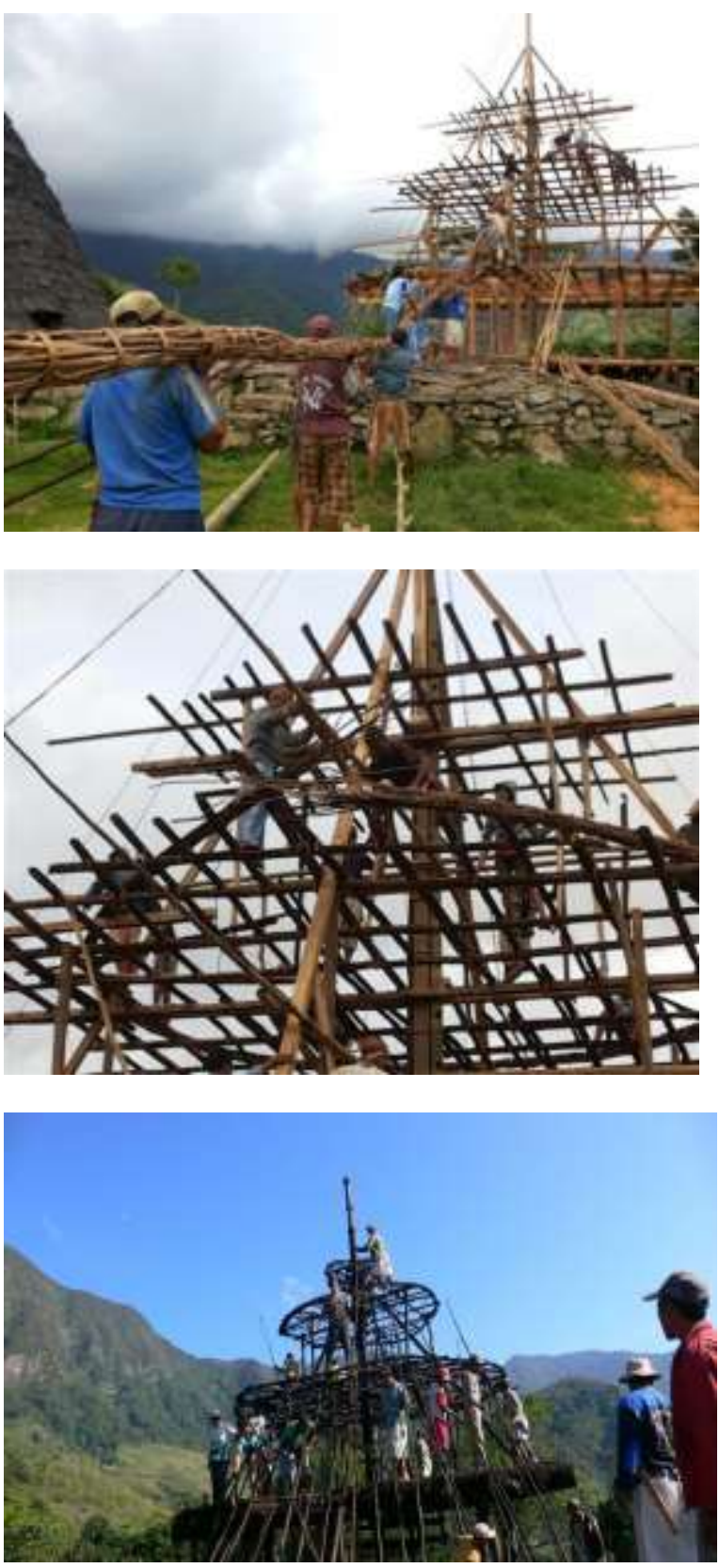

Gambar 11, 12, 13: Proses restorasi Mbaru Niang di Desa Waerebo, Flores

(Sumber: https://bandanaku.wordpress.com, diakses 08 Mei 2017)

\section{KESIMPULAN}

Kegiatan pelestarian bangunan bersejarah dalam hal ini bangunan yang termasuk dalam Cagar Budaya adalah salah satu keharusan bagi keselamatan warisan budaya bangsa. Salah satu kegiatan pelestarian tersebut adalah dengan menerapkan kegiatan restorasi baik minor maupun mayor pada bangunan Cagar Budaya. Bangunan bersejarah yang termasuk dalam Cagar Budaya bukan hanya bangunan-bangunan peninggalan era colonial, namun justru bangunan-bangunan tradisional yang memiliki karakter yang unik dari segala pelosok daerah Indonesia juga harus dilestarikan. Tulisan ini telah mencoba memberikan wacana mengenai kegiatan restorasi minor dan mayor pada rumah tradisional yaitu Rumah Tuo Kampai Nan Panjang di Sumatera Barat dan Rumah Wae Rebo di Flores. Keduanya memiliki karakter yang berbeda dengan budaya dan tradisi yang berbeda juga di daerahnya masing-masing. Kekuatan nilai sejarah, budaya dan tradisi dari kedua rumah tradisional tersebut memberikan karakter yang signifikan pada keduanya.

\section{REFERENSI}

Antar, Y. (2010). Pesan dari Wae Rebo: Kelahiran Kembali Arsitektur Nusantara, Sebuah Pelajaran dari Masa Lalu untuk Masa Depan. Jakarta: Gramedia Pustaka Utama.

Bahri, S., \& Purwantiasning, A. W. (2016). An Optimalization of Natural Lighting by Applying Automatic Lighting Using Motion Sensor and Lux Sensor for Historical Old Buildings. NALARs, 15(2), 131-140.

Membangun Mbaru Niang-Rumah Tradisional Waerebo. (2014). Retrieved from https://bandanaku.wordpress.com

Purwantiasning, A. W. (2017). Benang Merah Terbentuknya Pola Permukiman dan Pola Hunian Desa Bali Mula. NALARs, 17(1), 11-20.

Purwantiasning, A. W. ... Suniarti, P. M. P. S. (2018). Oral Tradition as a Source for Digging Up the Historty of Parakan as a Heritage City. International Conference of Civil and Environmental Engineering. Kuala Lumpur, Malaysia.

The Getty Conservation Institute. (2002). The Principles for the Conservation of Heritage Sites in China. China.

Undang-Undang RI No. 11 Tahun 2010 tentang Cagar Budaya. , Pub. L. No. Undang-Undang RI No. 11 (2010).

UNESCO. (2005). Convention on the Protection and Promotion of the Diversity of Cultural Expressions 2005. 